\title{
Penanaman Karakter Asma'ul Husna Pada Anak Usia Dini di PAUD ELPIST Temanggung
}

\author{
Yuni Setya Hartati ${ }^{1}$, Puteri Anggita Dewi ${ }^{2}$, Luluk Ifadah ${ }^{3}$ \\ Institut Islam Nahdlatul Ulama Temanggung ${ }^{123}$, Indonesia \\ stainutemanggungyunisetya72@gmail.com ${ }^{1}$, ideanggita@gmail.com², \\ bundaqotrunnada@gmail.com ${ }^{3}$
}

\begin{abstract}
This research intens to describe the implant of Asma"ul Husna characters to Early Children at PAUD Elpist Temanggung. The questions are how the institution implant the Asma'ul Husna values, what factors are considered to support and unsuport its efforts.This study uses aqualitative approach to the type of descriptive research. It is revealed that PAUD Elpist used mixed of both curriculum from the institution which based on Ahlus Sunnah wal jamaah an nahdliyah and the curriculum fom ministry of national education using some methods. As the supporting factors: the teachers have highly motivation and the medias are complete enough. The lack of attention from parents and books or articles about the proper methods are considered to be barrier factors. As recommendation, ministry of religious gives attention and aid to improve facility to Early Children Educatio. Institutions also need to facility some books or some articles related and give regular basic training to the teachers and handle some parenting education.
\end{abstract}

\begin{tabular}{lr} 
Abstrak & \\
\hline Penelitian ini bertujuan menggambarkan penanaman & Kata Kunci: \\
nilai karakter Asma'ul Husna pada anak usia dini di & Karakter Asmaul \\
PAUD Elpist Kabupaten Temanggung. Pertanyaan & Husna; \\
penelitian adalah bagaimana PAUD Elpist menanamkan & Anak Usia Dini. \\
nilai karakter Asma'ul Husna kepada peserta didiknya, & \\
faktor-faktor apakah yang mendukung maupun & \\
menghambatnya. Penelitian ini menggunakan & \\
pendekatan kualitatif dengan jenis penelitian & \\
deskriptif. Hasil penelitian menunjukkan bahwa dalam & \\
usaha penanaman nilai-nilai karakter Asma'ul Husna & \\
pada peseta didiknya, PAUD Elpist Temanggung & \\
memadukan kurikulum dari Yayasan yang berbasis & \\
Ahlus sunnah wal jamaah an nahdliyah, dan & \\
kemendiknas dengan menggunakan beragam metode. & \\
\hline
\end{tabular}


Faktor pendukung dalam implementasi ini adalah para guru memiliki pengetahuan dan motivasi yang tinggi serta sarana prasarana yang memadai. Sedangkan faktor penghambatnya adalah adanya wali murid yang kurang respek tehadap anak, serta minimnya buku atau artikel yang bisa diakses pendidik dalam memilih metode yang tepat. Sebagai rekomendasi agar Yayasan dan pengelola memfasilitasi kegiatan parenting yang melibatkan orang tua, serta memfasilitsi guru dengan buku-buku, atikel tentang metode-metode penerapan nilai kaakter Asma'ul Husna dan pelatihan-pelatihan yang relevan.

Diterima : 2 Juli 2021; Direvisi: 16 Agustus 2021; Diterbitkan: 28 Agustus 2021

http://doi.org/10.19105/kiddo.v2i1.3608

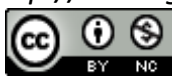

(C) Kiddo Jurnal Pendidikan Islam Anak Usia Dini Institut Agama Islam Negeri Madura, Indonesia

This is an open access article under the CC-BY-NC license

\section{Pendahuluan}

Perkembangan teknologi informasi yang begitu pesat pada era Revolusi Industri 4.0 memberikan tantangan sekaligus peluang strategis bagi generasi bangsa Indonesia. Sebagai negara yang mayoritas penduduknya beragama Islam, Indonesia berpeluang dalam mengisi kemajuan melalui upaya penguatan karakter generasi mudanya. Di pundak generasi muda memangku beban berat bagi kemajuan bangsa yang diawali dari fase dini perkembangannya.

Dewasa ini, karakter bangsa Indonesia telah banyak menyimpang dari norma-norma, baik norma hukum, norma sosial, bahkan norma agama. Orang-orang pada masa kini sedang mengalami sebuah krisis yang begitu hebat pengaruhnya bagi peradaban, yaitu krisis karakter. Melihat kenyataan itulah, pendidikan karakter perlu diberlakukan untuk di negeri ini. Pendidikan karakter dipilih sebagai suatu upaya perwujudan pembentukan karakter peserta didik ataupun generasi bangsa yang berakhlak mulia. Pendidikan karakter harus dilaksanakan sejak usia dini. (Hadisi, 2015).Salah satu nilai pendidikan karakter yang perlu ditanamkan sejak dini adalah nilai religius yang tercermin dalam keimanan dan ketaatan melaksanakan ajaran agama.

Sikap positif perlu ditanamkan pada anak sejak dini, melalui ucapan dan tindakan yang dicontohkan oleh orang dewasa, baik guru maupun orang tua. Penanaman sikap positif harus dilaksanakan secara terus-menerus. Hasil penanaman sikap tidak akan nampak dalam waktu singkat, namun membutuhkan proses yang cukup panjang. Oleh karena itu pendidikan karakter harus dilakukan sejak usia dini, sehingga ketika dewasa, anak menjadi generasi yang berkarakter. (Khaironi, 2017) Prinsip utama yang harus ditanamkan pada anak sejak usia dini adalah ketauhitan melalui penguatan pondasi iman yang pada tahap internaslisasinya dimulai dengan metode pembiasaan. Pembiasaan akan sangat mempengaruhi proses pembentukan karakter anak (Muhammad, 2013). Agar nilai-nilai ketauhidan muncul dalam diri 
anak, kita bisa mulai untuk mengenalkan Allah kepadanya. Salah satu upaya yang dapat kita lakukan adalah mengenalkan Asmaul Husna.

Asmaul Husna merupakan nama-nama Allah yang mulia danagung sebagai wujud kebesaran dan kekuasaan Allah atas alam semesta beserta segala isinya ini. Bagi seorang muslim salah satu cara mengenal Allah adalah dengan mempelajari sifat-sifat Allahsertamengenal 99 nama Allah (Syahrudin, 2019). Proses internalisasi nilai ajaran islam melalui pelafalan dan pengamalan menjadi sangat penting bagi peserta didik agar dapat diterapkan dalam kehidupan sehari-hari.

Meneladani asma Allah tidaklah sekadar mengakui diri kita sebagai hamba Allah. Terlebih hanya dengan memilihnya sebagai sebutan nama semisal 'Abdullah (hamba Allah), Abdurrahman (hamba arRahman), atau Abdurrahim (hamba ar-Rahim). Yang terpenting, kita harus membuktikan dan berusaha menghiasi diri dengan sifat-sifat terpuji sebagaimana yang terkandung dalam Asmaul Husna. Jika asma Allah dipahami secara benar, akan semakin mengukuhkan keyakinan pada kebesaran, kekuasaan, dan kasih saying Allah (Basori, 2018). Dengan hal tersebut, kita bisa menjadi hamba yang seutuhnya.

Melalui kegiatan pembiasaan pelafalan Asma'ul Husna merupakan bagian dari upaya manusia sebagai hamba dalam mendekati dan meneladani sifat-sifat Allah yang hanya melekat pada Allah sebagai sang pencipta dan tidak dimiliki oleh makhluk (yang diciptakan). Sebagaimana yang dimaksudkan dalam Al-Qur'an Surat Al- A'Raf ayat 180 bahwa dengan menyebut Asmaul Husna maka Allah akan memberikan balasan dengan menghindarkannya dari penyimpangan dan mengarahkan seseorang kepada tindakan kebenaran.

Masa usia dini adalah masa yang sangat penting bagi taraf pekembangan manusia di masa depan. Pada masa usia dini 0-6 tahun anak mengalami lompatan-lompatan pekembangan dalam hidupnya. Masa ini sering disebut dengan masa keemasan, karena stimulasi yang diberikan pada usia ini akan mudah diserap anak dan membekas hingga kelak saat mereka dewasa. Usia dini disebut juga dengan golden age karena fisik dan motorik anak berkembang dan bertumbuh dengan cepat, baik perkembangan emosional, intelektual maupun moral (Mursid, 2017). Selama masa inilah anak akan mudah menerima stimulus-stimulus yang diberikan kepadanya.

Kemajuan zaman yang berarti kemajuan ilmu pengetahuan bisa saja membawa dampak positif bagi masa depan peradaban. Akan tetapi, kemajuan ilmu pengetahuan tanpa diimbangi dengan norma agama akan membawa dampak negative bagi peserta didik. Kita tahu bahwa ilmu pengetahuan akan membawa manusia lepas dari keterbelakangan. Hanyasaja yang diberikan agama adalah berkesinambungan, sementara kekuatan yang diberikan ilmu pengetahuan cenderung terputus-putus. Ilmu pengetahuan mampu memperindah akal pikiran, sementara agama mampu memperindah perasaan (Illahi, 2012). Nilai moral agama seseorang merupakan hal yang sangat penting dalam kehidupan. Betapapun tinggi ilmu seseorang jika tidak dilandasi dengan nilai agama dan moral yang kuat maka tidak akan bisa membawa diri mereka mempeoleh ridlo Nya. 
Penanaman nilai-nilai moral keagamaan menjadi hal yang sangat mendesak pada era milenial ini. Pada era ini perkembangan teknologi yang sedemikian pesatnya hingga apapun bisa dengan mudah diakses semua kalangan. Nilai nilai positif bisa dengan mudah diakses, akan tetapi nilai-nilai negative juga tak kalah mudahnya diakses. Sebagai oang tua tentunya kita tidak ingin anak-anak kita terjerumus menggunakan kemajuan teknologi secara tidak benar. Penanaman nilai-nilai moral keagamaan sejak dini diharapkan menjadi salah satu solusi untuk meminimalisir terjadinya hal tersebut.

Penelitian-penelitian dalam penanaman karakter telah dilakukan. Penanaman karakter telah dilakukan dengan berbaga cara. Penelitian yang dilkukan oleh Moh. Ahsanulhaq (2019) meneliti tentang pembentukan karakter pada anak SMP Negeri 2 Bae Kudus dengan judul "Membentuk Karakter Religius Peserta Didik Melalui Metode Pembiasaan". Penelitian selanjutnya dilakukan oleh Yudha Pradana (2016) tentang pengembangan karakter siswa melaluibudaya sekolah di SD Amaliyah Ciawi Bogor. Penelitian tentang penenaman karakter juga dilakukan oleh Intan Pertiwi (2020). Intan Pertiwi meneliti tentang penanaman religious siswa melalui pembiasaan membaca Asmaul Husna di MTs Ma'arif Mojopurno Magetan.Penanaman karakter yang diteliti di atas adalah penelitian terhadap anak usia lebih dari enam tahun, dimana pada usia tersebut mereka telah melampaui masa keemasan. Menurut penulis penerapan karakter akan lebih efektif jika dilakukan sejak usia dini.

Penelitian ini peneliti lakukan dengan tujuan menggambarkan penanaman nilai karakter Asma'ul Husna pada anak usia dini di PAUD Elpist Kabupaten Temanggung. Pertanyaan penelitian adalah bagaimana PAUD Elpist menanamkan nilai karakter Asma'ul Husna kepada peserta didiknya, faktor-faktor apakah yang mendukung maupun menghambatnya. Dengan penelitian ini dihasilkan metode penerapan yang lebih variatif yang bisa diterapkan dalam penanaman karakter pada anak.

\section{Metode}

Metode penelitian yang digunakan dalam penelitian ini adalah metode deskriptif dengan pendekatan kualitatif. Peneliti berusaha untuk menganalisis dan meneliti masalah yang terjadi pada masa sekarang. Dalam penelitian ini peneliti tidak membuat perbandingan variabel pada sampel yang lain. Peneliti dalam mengumpulkan dan menganalisis data menjadi bagian dari proses penelitian sebagai partisipan bersama informan yang memberikan data.

\section{Hasil dan Pembahasan}

Pertanyaan penelitian seperti yang telah diuraikan dalam pendahuluan adalah bagaimana PAUD Elpist menanamkan nilai karakter Asma'ul Husna kepada peserta didiknya, serta faktor-faktor apakah yang mendukung maupun menghambatnya. Hasil penelitian dan pembahasan akan peneliti uraikan pada bagian ini.

\section{Metode Penanaman Karakter Asmaul Husna di PAUD Elpist Temanggung}


Setiap nama pastilah berkaitan erat dengan apa yang dinamai. Demikian juga dengan nama Allah yang dikenal dengan Asmaul Husna ini. Asmaul Husna adalah bacaan dzikir dan do'a yang sangat istimewa, karena didalam bacaan dzikir asmaul husna ini mengandung banyak manfaatyang barang siapa membacanya Allah telah menjanjikan masuk surga(Qomariyah, 2019).Dengan mengenal dan meresapi makna nama-nama Allah lebih dalam, kita bisa merasakan bahwa Allah begitu dekat.

Allah memiliki sembilan puluh sembilan Asmaul Husna. Masingmasing nama dari Asmaul Husna ini menunjukkan sifat Allah yang Mahasempurna. Sifat-sifat Allah berbeda dengan sifat semua makhluknya, Allah suci dari sifat kekurangan (Abbas, 2021). Namanama Allah yang berjumlah 99 nama mengandung sifat positif yang hanya dimiliki Sang Pencipta dan mengisyaratkan makna agar menjadi rujukan bagi sifat manusia sekaligus menjadi pedoman dalam menjalankan kehidupan. Sifat Allah dengan segala ke-Maha-an-nya memberikan petunjuk bagi jalan kebaikan seseorang sehingga pemahaman akan asma'ul husna diharapkan mampu tercermin dalam perilaku sehari hari, tentunya hal tersebut diperoleh dari proses pendidikan.

Pembelajaran pada hakekatnya adalah proses interaksi antara peserta didik dengan lingkungannya, sehingga terjadi perubahan perilaku ke arah yang lebih baik (Mintarsih, 2016). Keadaan tempat anak belajar turut mempengaruhi keberhasilan pendidikan, salah satunya di sekolah.

Suatu pembelajaran yang baik salah satu indikasinya adalah pembelajaran yang mampi memberikan pengalaman luar biasa dan memberikan inspirasi bagi peserta didiknya. Peserta didik dalam hal ini tentu saja sangat mendambakan pembelajaran yang menarik (Syafriafdi, 2020). Kualitas guru, metode mengajarnya, kesesuaian kurikulum dengan kemampuan anak, keadaan fasilitas atau perlengkapan di sekolah, pelaksanaan tata tertib dan sebagainya, semua ini turutmempengaruhi pendidikan anak. Sekolah merupakan lingkungan pendidikan yang sengaja dirancang dengan aturan yang berjenjangdan berkesinambungan sehingga disebut pendidikan formal (Nadziroh, 2018). Menerapkan pendidikan karakter memanglah tak semudah membalikkan telapak tangan, terlebih ditengah tugas-tugas administratif para pendidik.

Jika pendidikan karakter berarti suatu cara untuk memahamkan siswa tentang moral atau berperilaku yang baik maka tentu lebih mudah bila kita memberikan pengalaman langsung yang sepenuhnya melibatkan pemikiran dan peran aktif peserta didik daripada menyeragamkan nilai-nilai moral pada anak-anak kita (Muaddab, 2011). Hal ini disebabkan nilai moral bersifat relatif pada masingmasing pribadi manusia.

Lembaga atau organisasi pendidikan baik formal, non formal, maupun informal merupakan bagian integral dari sistem pendidikan nasional yang keberadaannya harus terus menerus dikuatkan (Triyono, 2019). Pendidik sebagai pelaksana pendidikan formal memerlukan seperangkat metode untuk mencapai hasil yang diinginkan. Metode 
adalah suatu cara yang ditempuh dalam memperoleh sesuatu yang diharapkan. Dalam penaman karakter Asma'ul Husna, PIAUD Elpist menerapkan atau menggunakan beberapa metode. Dengan menggunakan berbagai metode tersebut diharapkan karakter Asma'ul Husna akan lebih mudah diserap anak dan kelak mereka mampu mengaplikasikannya dalam kehidupan sehari-hari.

Tahap penanaman nilai karakter Asma'ul Husna dapat dilakukan oleh pendidik dengan mengenalkan Allah melalui sifat-sifatNya. Penanaman karakter Asma'ul Husna atau nama-nama Allah yang baik di PAUDElpist Temanggung dilakukan melalui enam metode.

Pertama, metode audio visual. Dengan audio visual, selain anak melihat dan mendengar nama nama Allah dan maksud atau arti dari nama tersebut. Metode ini efektif dalam memberikan stimulasi perkembangan kognisi maupun afeksi anak dalam mencerna makna Asma'ul Husna

Kedua, metode peneladanan. Metode peneladanan merupakan metode yang lebih banyak menekankan peran guru dalam menjadi figur percontohan langsung bagi baik dalam proses pembelajaran di kelas maupun dalam kegiatan lainnya diluar kelas. Peneladanan atau percontohan langsung dari pendidik memberikan pengaruh besar pada psikomotorik anak untuk meniru dan mendalami makna Asma'ul Husna yang tercermin dalam perilaku pendidiknya.

Ketiga, metode tanya jawab. Metode tanya jawab diaktualisasikan sebagai bagian dari cara mengkomunikasikan kemauan dan ide pembelajaran kepada anak melalui kemasan intereaktif sehingga anak mampu berkomunikasi kepada lawan bicara baik secara verbal amupun non verbal. Dengan metode tanya jawab dalam proses komunikasi yang interaktif inilah proses penanaman nilai Asma'ul Husna dapat berlangsung secara bertahap tanpa adanya kesan intimidatif.

Keempat, metode bercerita. Metode bercerita digunakan dengan maksud agar dapat mengasah kemampuan imajinasi anak dalam menginterpretasikan pesan yang terkandung dalam sebuah cerita. Didalam proses mendengarkan dan memperhatikan cerita, dimaksudkan agar anak mampu menyerap nilai Asma'ul Husna secara mendalam.

Kelima, metode pembiasaan. Metode pembiasaan merupakan salah satu tahapan metode yang cukup berpengaruh secara signifikan dalam membentuk perilaku anak. Melalui pembiasaan hadirlah sebuah karakter. Dengan pembiasaan berperilaku yang mencerminkan karakter asma'ul husna, maka anak akan berproses dan terbentuk menjadi pribadi yang syarat dengan nilai nilai kebaikan Allah.

Keenam, metode demonstrasi. Metode demonstrasi merupakan metode memperagakan cara untuk melakukan sesuatu. Yakni dengan mempraktekkan nama Allah dalam kegiatan anak secara terbimbing sehingga anak memeahami dan mempraktekkan makna asma'ul Husna secara langsung.

\section{Faktor Pendukung dan Penghambat Penanaman Karakter Asmaul Husna di PAUD Elpist Temanggung}


Pendidikan selalu berlangsung dengan berbagai dinamika yang mengiringinya. Keberhasilan penanaman karakter anak tak hanya menjadi tanggungjawab pihak sekolah, namun juga keluarga. Dalam prosesnya, banyak sekali faktor-faktor yang mempengaruhi terlaksananya penanaman karakter asmaul husna di PAUD ELPIST.Faktor-faktor tersebut bisa menjadi faktor pendukung dan ada juga yang menjadi faktor penghambat. Begitupun dalam penanaman karakter Asmaul Husna di PAUD Elpist Temanggung, selain faktor pendukung dijumpai juga faktor penghambat dalam pelaksanaannya.

\section{a. Faktor Pendukung}

Keberhasilan penanaman karakter Asmaul Husna di PAUD Elpist Temanggung didukung oleh faktor latar belakang pemahaman keluarga, serta pemahaman dan kemampuan pendidik dalam penyampaian nilai karakter Asma'ul Husna.

Pertama latar belakang pemahaman keagamaan orang tua khususnya tentang nilai karakter Asmaul Husna.. Pemahaman orang tua akan Asmaul Husna menjadi hal yang berpengaruh dalam menanamkan karakter Asmaul Husna. Anak yang hidup dalam lingkungan keluarga yang religius, khususnya ahlus sunnah wal jama'ah an nahdliyah tentu saja tidak mengalami kesulitan berarti dalam mempelajari Asma'ul Husna baik sebagai bacaan/wirid sekaligus amaliah harian bagi semua anggota keluarga. Anak yang telah terbiasa dengan bacaan Asma'ul Husna akan merasa nyaman dalam melafadzkan, menghafalkan, memahami serta mempraktekkan nilainilai pembentukan karakter yang terkandung didalam Asma'ul Husna tersebut.

Kedua, pemahaman dan kemampuan pendidik dalam penyampaian nilai karakter Asma'ul Husna. Selain pemahaman orang tua, pemahaman dan kemampuan pendidik dalam penyampaian karakter Asmaul Husna juga menjadi titik poin yang sangat penting.

\section{b. Faktor Penghambat}

Ada beberapa hal yang menghambat proses penanaman karakter pada anak. Pertama, minimnya pemahaman keagamaan orang tua. Dengan adanya hal tersebut, secara tidak langsung orangtua membebankan tanggungjawab pendidikan agama islam dan karakter asma'ul husna kepada lingkungan pendidikan anak diluar rumah. Sehingga kewajiban memahami ajaran dan nilai-nilai agama islam dibebankan kepada anak dan penanggungjawab utamanya adalah pendidik di ELPIST. Hal ini menjadikan ketidaksinkronan pola pendidikan dan nilai ajaran yang disampaikan oleh pendidik di sekolah dan orang tua sebagai pendidik utama dirumah. Inilah yang menjadikan dominasi pemahaman nilai agama anak hanya bersifat temporal dan tidak dilaksanakan secara integratif. Kedua, kesibukan orang tua dalam bekerja. Hal ini berdampak pada menurunnya kualitas pendidikan di rumah dan tidak terpenuhinya kuantitas pemberian pendidikan agama anak. Hal ini pun berdampak signifikan bagi pemerolehan kasih sayang orangtua dan ekspresi tulus orang tua yang tercermin dalam kegiatan keagamaan di dalam keluarga. Ketiga, kurangnya sumber sumber referensi dalam penanaman nilai karakter Asma'ul Husna. Referensi yang dimaksudkan disini adalah referensi 
baik berupa materi, video, sumber bacaan serta bahan ajar lain yang berdampak pada kurang maksimalnya pemberian pemahaman kepada anak tentang Asma'ul Husna.

\section{c. Upaya Mengatasi Hambatan}

Dari hasil wawancara yang dilakukan kepada guru dan Kepala PAUD diperoleh informasi bahwa pada awalnya ditemui berbagai hambatan dalam penanaman nilai karakter Asmaul husna ini. Berbagai strategi dilakukan untuk mengatasi hambatan-hambatan. Pertama, mengadakan kegiatan parenting. Parenting tersebut dilakukan secara rutin dihadiri oleh orang tua/wali murid sehingga terjadi kesinambungan antara pembelajaran Asmaul Husna bagi anak baik dilingkungan sekolah maupun di lingkungan rumah. Kedua, pengadaan buku panduan do'a. Buku panduan do'a digunakan sebagai sumber media dan referensi dalam memperdalam ajaran agama baik bagi pendidik, peserta didik maupun wali murid. Ketiga, pengadaan buku penghubung. Adanya buku penghubung bertujuan menjembatani komunikasi dan interaksi antara pendidik dan orang tua. Melalui buku ini orangtua akan memahami perkembangan tumbuh kembang anak selama menempuh pembelajaran.

\section{Kesimpulan}

Penanaman nilai karakter Asma'ul Husna penting dilakukan pada anak sejak usia dini dengan melalui pembiasaan sehari-hari sehingga tanpa terasa mereka mengaplikasikan nilai karrakter tersebut dalam kehidupan sehari-hari hingga dewasa nanti. Asma'ul Husna yang merupakan nama-nama Allah yang baik telah menginspirasi pendiri PIAUD Elpist

PAUD Elpist Temanggung sudah menanamkan nilai karakter Asma'ul Husna kepada peseta didiknya dengan melalui berbagai metode yang diupayakan semaksimal mungkin disesuaikan dengan karakter masing-masing anak. Dalam usaha penanaman nilai-nilai karakter Asma'ul Husna pada peserta didiknya, PAUD Elpist Temanggung memadukan kurikulum dari Yayasan yang berbasis Ahlus sunnah wal jamaah an nahdliyah, dengan kurikulum PAUD dari Kementerian Pendidikan Nasional

Faktor-faktor pendukung bagi penanaman nilai karakter Asma'ul Husna di PAUD Elpist adalah para guru yang memiliki pengetahuan dan motifasi yang tinggi serta sarana prasarana yang cukup memadai. Sedangkan faktor penghambat upaya penanaman nilai karakter Asma'ul Husna yang dirasakan oleh pendidik adalah adanya wali murid yang kurang respek tehadap anak, serta minimnya buku atau artikel yang bisa diakses pendidik dalam memilih metode yang tepat.

Penanaman nilai karakter Asmaul Husna akan sangat baik dan berhasil jika didukung oleh berbagai pihak terkait antara lain: Yayasan, pengelola, kementerian agama dan kementrian pendidikan nasional yang memfasilitasi kegiatan parenting yang melibatkan orang tua, serta memfasilitsi guru dengan buku-buku, artikel tentang metode-metode penerapan nilai karakter Asma'ul Husna dan pelatihanpelatihan yang relevan dan segenap pendidik dan tenaga kependidikan di lingkungan PAUD. 


\section{Daftar Pustaka}

Abbas, Abu Azka Ibn. (2021). Mengenal Asmaul Husna. CV. Titian Ilmu : Bandung.

Ahsanulkhaq, M. (2019). Membentuk Karakter Religius Peserta Didik Melalui Metode Pembiasaan. Jurnal Prakarsa Paedagogia, 2(1).

Basori, Khabib. (2018). Berakhlak dengan Asmaul Husna. Penerbit Cempaka Putih : Klaten.

Hadisi, L. (2015). Pendidikan karakter pada anak usia dini. Al-TA'DIB: Jurnal Kajian Ilmu Kependidikan, 8(2), 50-69.

Ilahi, M. T., \& Ratri, R. K. (2012). Revitalisasi pendidikan berbasis moral. Ar-Ruzz Media.

Mintarsih, M. (2016). Penerapan Metode Inkuiri melalui Media Gambar Berorientasi Lingkungan Sekitar dalam Pembelajaran Menulis Paragraf Pada Siswa Kelas IVSD Pertiwi Kota Bandung (Doctoral dissertation, Universitas Pendidikan Indonesia).

Muaddab, H. (2011). Membangun gerakan moral di sekolah. CV. Garuda Mas Sejahtera : Tebuireng Institute.

Muhammad Fadillah dan Lilif Mualifatu Khorida. 2013. Pendidikan Karakter Anak Usia Dini: Konsep \& Aplikasinya dalam PAUD. Jogjakarta: Ar-Ruzz Media.

Mursid, M. 2017. Manajemen Pemasaran. Jakarta : Bumi Aksara.hlm-2

Nadziroh, I. (2018). Pengaruh Tripusat Pendidikan Terhadap Akhlakul Karimah Siswa Kelas X Madrasah Aliyah Ma'arif Udanawu Blitar.

Pradana, Y. (2019). Pengembangan Karakter Siswa Melalui Budaya Sekolah. Untirta Civic Education Journal, 1(1).

Pratiwi, I. (2020). Internalisasi Karakter Religius Siswa Melalui Pembiasaan Membaca Asmaul Husna Di MTs Ma'arif Mojopurno Magetan (Doctoral dissertation, IAIN Ponorogo).

Triyono, U. (2019). Kepemimpinan Transformasional dalam Pendidikan:(Formal, Non Formal, dan Informal). Penerbit Deepublish : Yogyakarta.

Syafriafdi, N. (2020). Menjadi Guru Hebat di Era Revolusi Industri 4.0. Penerbit Deepublish : Yogyakarta

Syahrudin, S. (2019). Penanaman Akidah pada Anak Usia Dini Melalui Penerapan Kurikulum Berbasis Asmaul Husna. Tarbiyatuna: Jurnal Pendidikan IImiah, 4(1), 1-25. Khaironi, M. (2017). Pendidikan karakter anak usia dini. Jurnal Golden Age, 1(02), 82-89.

Qomariyah, Siti. (2019). Pengenalan Asma'ul Husna Anak Usia Dini Melalui. Model Pembelajaran Sentra Imtaq di RA Ar-Rafif Kalasan Sleman. Skripsi : Yogyakarta 